\title{
Preventive Effect of Fluoridated Orthodontic Resins Subjected to High Cariogenic Challenges
}

\author{
Paula PASSALINI \\ Tatiana Kelly da Silva FIDALGO \\ Erika Machado CALDEIRA \\ Rogerio GLEISER \\ Matilde da Cunha Gonçalves NOJIMA \\ Lucianne Cople MAIA \\ Department of Pediatric Dentistry and Orthodontics, Dental School, \\ Federal University of Rio de Janeiro, Rio de Janeiro, RJ, Brazil
}

\begin{abstract}
The aim of the present study was to evaluate the in vitro caries preventive effect of fluoridated orthodontic resins under $\mathrm{pH}$ cycling with two types of acid demineralizing saliva. Brackets were bonded to 60 bovine incisors, using either Transbond Plus Color Change $(n=30)$ or Orthodontic Fill Magic $(n=30)$ orthodontic resins. Each group of resin was divided into 3 subgroups $(n=10)$ : immersion in remineralizing artificial saliva for 14 days, $\mathrm{pH}$ cycling with high cariogenic challenge in acid saliva with $\mathrm{pH} 5.5$, and acid saliva with $\mathrm{pH}$ 4.5. After 14 days of $\mathrm{pH}$ cycling, the caries preventive effect on the development of white spot lesion was evaluated considering the presence of inhibition zones to white spot lesions using two scores: $0=$ absence and $1=$ presence. Kruskal Wallis and MannWhitney tests $(\alpha=0.05)$ were used. Formation of white spot lesions was observed only under $\mathrm{pH}$ cycling using acid saliva with $\mathrm{pH}$ 4.5; with Transbond Plus Color Change being significantly more effective $(p<0.05)$ in preventing the appearance of white spot lesions effect than Orthodontic Fill Magic. The acidity of the demineralizing solution influenced the formation of white spot lesions around orthodontic brackets under highly cariogenic conditions. Transbond Plus Color Change resin presented higher caries preventive effect than Orthodontic Fill Magic.
\end{abstract}

Key Words: demineralization, remineralization, fluoride, orthodontic, bracket.

\section{INTRODUCTION}

Mechanical characteristics of orthodontic materials used to bond devices are frequently investigated in the literature (1-4). However, the biologic effect of these materials on the teeth is also important, since orthodontic treatment should maintain the health of oral tissues (2). Despite the worldwide decrease of dental caries prevalence, the development of white spot lesions (WSL) around orthodontic brackets continues to be a problem, especially because orthodontic devices facilitate biofilm the retention of biofilm, frequently causing gingivitis (5). The prevalence of WSL is 50\% among patients that undergo comprehensive orthodontic treatment. The unaesthetic aspect caused by WSLs may remain even after the brackets are removed $(5,6)$.

Prevention of WSL has been the main purpose of a number of studies that use orthodontic materials with this intrinsic preventive capacity (5-7). The most important characteristic of glass ionomer cements is their anticariogenic property, due to their capacity to release and store fluoride. However, the disadvantage of glass ionomer cements for orthodontic use is their low bond strength to dental substrate (8). To solve this problem, materials with high bond strength associated with fluoride-releasing capacity, such as fluoridated composite resins, have been developed (7).

Although in vitro studies highlight the advantages of fluoride in orthodontic materials $(6,7)$, there are few reports on the real influence of simulating the oral environment in the caries preventive effect of these materials. Thus, this study investigated the in vitro caries preventive effect of fluoridated orthodontic resins under conditions that simulate high cariogenic challenge with

Correspondence: Dra. Lucianne Cople Maia, Rua Gastão Gonçalves 47/501, Santa Rosa, 24240-030 Niterói, RJ, Brasil. Tel/Fax: +55-21-2629-3738. e-mail: rorefa@terra.com.br 
two types of acid demineralizing saliva.

\section{MATERIAL AND METHODS}

\section{Specimen Preparation}

The specimens were prepared by sectioning $3 / 4$ inch cylindrical PVC tubes to obtain 1-cm-high cylinders, used as molds. Sixty bovine incisors were sectioned along the cementoenamel junction. The crowns were embedded in epoxy resin with the buccal surface facing the glass plate. Silicon carbide abrasive papers with successive grits (180, 400 and 600; 3M do Brasil Ltd, Sumaré, SP, Brazil) were used to remove excess resin and to expose the bonding area. The coronal portion was subjected to prophylaxis with prophylactic rubber cups at low speed, and extra-thin pumice (S.S. White, Rio de Janeiro, RJ, Brazil) for $5 \mathrm{~s}$. Specimens were washed in deionized water for $15 \mathrm{~s}$, and dried with an oil-free air jet and water vapor for the same period of time.

The bonding area of each crown was located in the most central area of the middle third of the buccal surface. Maxillary central incisor brackets were used (Edgewise System; Morelli, Rio de Janeiro, RJ, Brazil) and 2 different orthodontic light polymerized fluoridated resins were chosen for bonding: Transbond Plus Color Change ( $\mathrm{n}=30$, TSEP; 3M Unitek, Monrovia, CA, USA) and Orthodontic Fill Magic ( $n=30$, Vigodent, Rio de Janeiro, RJ, Brazil). For the Transbond Plus Color Change resin, Transbond Plus Self Etching Primer (3M Unitek) was used. For the Orthodontic Fill Magic resin, the enamel was previously etched with $37 \%$

Table 1. Distribution of specimens to the Transbond Plus Color Change $(n=30)$ and Orthodontic Fill Magic $(n=30)$ groups.

\begin{tabular}{lcc}
\hline Groups $(\mathrm{n}=10)$ & Fluoridated orthodontic resins & Treatments \\
\hline Control & $\begin{array}{c}\text { Transbond Plus / } \\
\text { Self-Etching Primer }\end{array}$ & Artificial saliva pH 7.0* \\
Control & $\begin{array}{c}\text { Ortodontic Fill Magic } \\
\text { Transbond Plus / }\end{array}$ & Artificial saliva pH 7.0* \\
Experimental & Self-Etching Primer & pH cycling 5.5 \\
Experimental & Ortodontic Fill Magic & pH cycling 5.5 \\
Experimental & $\begin{array}{l}\text { Transbond Plus / } \\
\text { Self-Etching Primer }\end{array}$ & $\mathrm{pH}$ cycling 4.5 \\
Experimental & Ortodontic Fill Magic & $\mathrm{pH}$ cycling 4.5 \\
\hline
\end{tabular}

*Groups not subjected to $\mathrm{pH}$ challenge. phosphoric acid (S.S. White) for $30 \mathrm{~s}$, coated with a onecomponent adhesive resin, according to the respective manufacturers' instructions. The specimens were stored in deionized water at room temperature for $24 \mathrm{~h}$.

\section{pH Cycling Conditions (Cariogenic Challenge Simulation)}

Exactly $24 \mathrm{~h}$ after bonding, all specimens were randomly allocated to control and experimental groups (Table 1). Groups of 10 specimens of each resin were formed according to the a) immersion in artificial remineralizing saliva (negative control groups); b) $\mathrm{pH}$ cycling with high cariogenic challenge in acid saliva with $\mathrm{pH} 5.5$; c) $\mathrm{pH}$ cycling with high cariogenic challenge in acid saliva with $\mathrm{pH} 4.5$.

The groups were subjected to modified cariogenic $\mathrm{pH}$ cycling according to Queiroz et al. (9). The $\mathrm{pH}$ cycling consisted in remained daily in demineralizing saliva ( $3 \mathrm{mmol} / \mathrm{L}$ calcium, $3 \mathrm{mmol}$ phosphate, $50 \mathrm{~mL} / \mathrm{L}$ acetic acid, and $0.308 \mathrm{~g}$ ammonium acetate, adjusted to $\mathrm{pH} 4.5$ or $\mathrm{pH} 5.5$ with sodium hydroxide) (10) for $22 \mathrm{~h}$ consecutively. After being washed with deionized water, they were kept for $2 \mathrm{~h}$ in contact with remineralizing saliva $(1.54 \mathrm{mmol} / \mathrm{L}$ calcium, $1.54 \mathrm{mmol}$ phosphate, $20 \mathrm{mmol} / \mathrm{L}$ acetic acid and $0.308 \mathrm{~g}$ ammonium acetate, adjusted to $\mathrm{pH} 7.0$ with potassium hydroxide) (11), completing a cycle of $24 \mathrm{~h}$. During the period of $\mathrm{pH}$ cycling, the specimens were kept in an incubator (Fanem Ltd, São Paulo, SP, Brazil), at a constant temperature of $37^{\circ} \mathrm{C}$ in order to simulate the oral environment. This dynamics was reproduced for the period of 14 days, during which the artificial saliva was renewed (neutral and acid) every 2 days.

\section{Evaluation of Caries Preventive Effect - WSL Inhibition Zone}

The caries preventive effect was evaluated through the presence of opaque, roughness, WSL by macroscopic observation. The enamel surfaces were classified by 2 trained calibrated examiners, according to the presence or absence of WSL inhibition zone around the orthodontic bracket, which were scored 0 or 1 , respectively. The experiment was conducted in doubleblinded fashion. 


\section{Statistical Analysis}

The WSL inhibition zone data were inserted in the database of the statistical program SPSS 16.0 (SPSS Inc, Chicago, IL, USA). The scores were subjected to statistical analyses by the Kruskal-Wallis and ManWhitney tests. The inter-rater agreement Kappa test was calculated to evaluate the agreement of the presence or absence of WSL inhibition zone. All statistical tests were performed with a confidence interval of $95 \%(p<0.05)$.

\section{RESULTS}

The inter-examiner kappa was 0.818 , demonstrating a satisfactory accordance in outcome measure.

The acid saliva with $\mathrm{pH} 5.5$ was not able to produce WSL, and thus the WSL inhibition zone was not evaluated. Formation of WSL was observed only under high cariogenic challenge in acid saliva with $\mathrm{pH} 4.5$.

Presence of total or partial inhibition zone of WSL formation was verified in $100 \%$ of the Transbond Plus Color Change resin specimens (Fig. 1A-C and Table 2), while only $30 \%$ of the Orthodontic Fill Magic specimens $(p<0.05)$ showed these inhibition zone formations (Fig. 1D-F and Table 2).

\section{DISCUSSION}

A unique feature of this research is the use of artificial saliva of demineralizing solutions with different $\mathrm{pH}$ to simulate the oral environment. The mechanical properties of bond orthodontic materials are largely studied (2-4), although there are few works

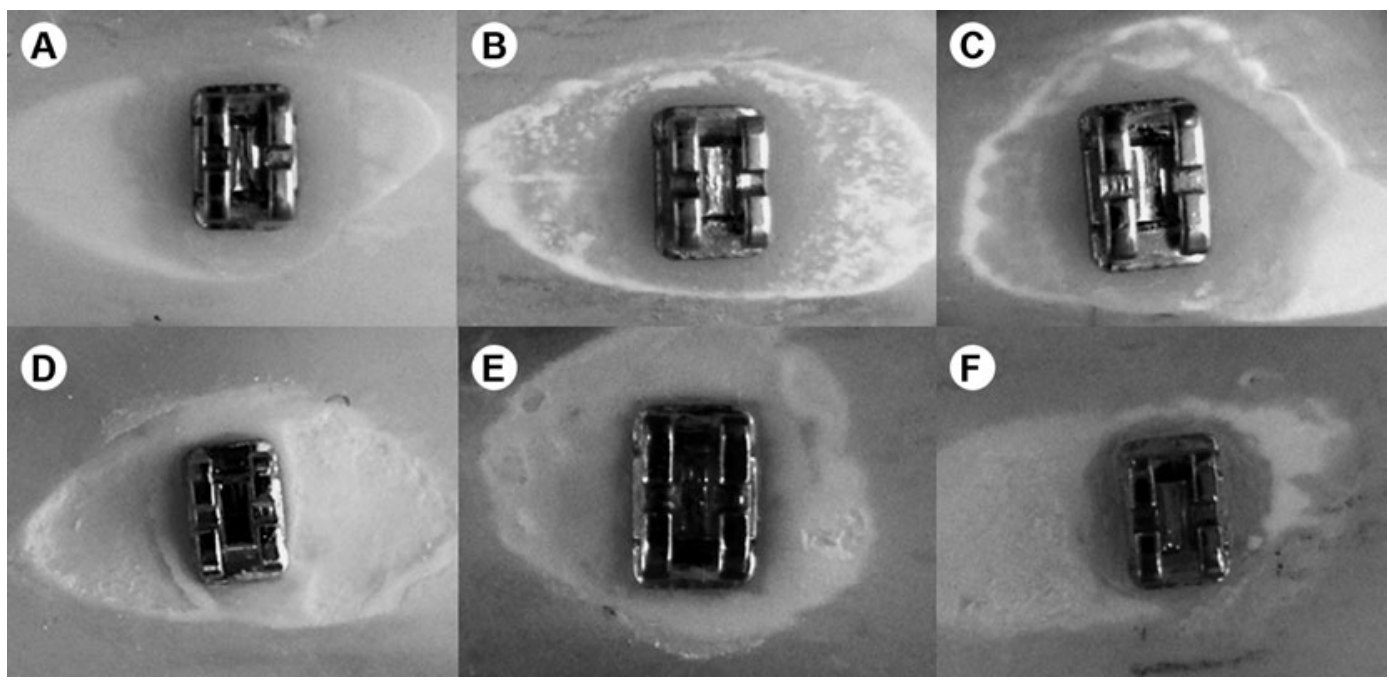

Figure 1. Specimens subjected to high cariogenic challenge at $\mathrm{pH}$ 4.5. A-C $=$ White spot lesion inhibition zones in brackets bonded with Transbond Plus Color Change. D-F = White spot lesion inhibition zones in brackets bonded with Orthodontic Fill Magic.

Table 2. Formation of white spot lesion inhibition zones around orthodontic brackets bonded with the two fluoridated orthodontic resins subjected to high cariogenic challenges.

\begin{tabular}{lcccccc}
\hline $\begin{array}{l}\text { Inhibition } \\
\text { zone }\end{array}$ & $\begin{array}{c}\text { TBP } \\
(\mathrm{pH} \mathrm{7.0)}\end{array}$ & $\begin{array}{c}\text { OFM } \\
(\mathrm{pH} \mathrm{7.0)}\end{array}$ & $\begin{array}{c}\text { TBP } \\
(\mathrm{pH} \text { cycling 5.5) }\end{array}$ & $\begin{array}{c}\text { OFM } \\
(\mathrm{pH} \text { cycling 5.5) }\end{array}$ & $\begin{array}{c}\text { TBP } \\
(\mathrm{pH} \text { cycling 4.5) }\end{array}$ & $\begin{array}{c}\text { OFM } \\
(\mathrm{pH} \text { cycling 4.5) }\end{array}$ \\
\hline Score 0 & $\begin{array}{c}\text { No } \mathrm{pH} \\
\text { cycling } \mathrm{x}\end{array}$ & $\begin{array}{c}\text { No } \mathrm{pH} \\
\text { cycling }\end{array}$ & No WSL & No WSL & $0^{*}$ & $70^{*}$ \\
Score 1 & $\begin{array}{c}\text { No } \mathrm{pH} \\
\text { cycling } \mathrm{x}\end{array}$ & $\begin{array}{c}\text { No } \mathrm{pH} \\
\text { cycling }\end{array}$ & No WSL & No WSL & $100^{*}$ & $30^{*}$ \\
\hline
\end{tabular}

TBP $=$ Transbond Plus Color Change; OFM = Orthodontic Fill Magic; $\mathrm{x}=$ not subjected to $\mathrm{pH}$ cycling (negative control groups); no WSL = no white spot lesion detected after $\mathrm{pH}$ cycling; *Statistical significance at 5\% (Kruskal-Wallis and Mann-Whitney tests). 
in current literature regarding to the preventive effect of fluoridated orthodontic resins under high cariogenic challenge simulation $(5,12)$. While most studies have induced demineralization using an acid solution (13), the present work evaluated the preventive effect of fluoridated orthodontic resins by simulating the oral environment, through cariogenic challenge reproduction using artificial saliva. In the present study, a strongly high cariogenic challenge was used to simulate oral environment, since cariogenic microorganisms were not used. $\mathrm{pH}$ cycling is largely used to evaluate therapeutic fluoride compounds $(9,14)$. However, to the best of our knowledge, this was the first study to evaluate the preventive effect of fluoridated orthodontic resins subjected to high cariogenic challenge.

Fluoride incorporation into the dental tissue reduces its solubility in acidic environments. This property is based on the capacity of fluoride to be incorporated into the crystalline lattice of the hydroxyapatite of dental hard tissues, resulting in a mineral phase that is less soluble and more acid resistant (13). Nevertheless, the influence of fluoride release in orthodontic resins, under conditions simulating high cariogenic challenge, is not well known. This study showed that the fluoride in Transbond Plus Color Change resin was able of inhibit WSL around orthodontic brackets, corroborating the findings in the literature (15) even under conditions of high cariogenic challenge in acid saliva with $\mathrm{pH} 4.5$ during a period of 14 days of $\mathrm{pH}$ cycling.

When the specimens were exposed to high cariogenic challenge at a $\mathrm{pH}$ that leads to hydroxyapatite dissolution ( $\mathrm{pH}$ 5.5), there was no WSL in any of the tested resins. In these cases, the fluoride might have worked as a demineralization inhibitor. It seems that during the demineralization dynamics, fluoride released from the resins and free calcium in the artificial saliva reincorporated into the dental substrate, forming fluoridated hydroxyapatite and calcium fluoride on the dental surface. As fluoridated hydroxyapatite is more resistant to high cariogenic challenge, it was only dissociated at $\mathrm{pH} 4.5$, and thus $\mathrm{pH} 5.5$ was not enough to produce WSL around orthodontic brackets in the present study.

When the specimens were subjected to a $\mathrm{pH}$ that leads to fluoridated hydroxyapatite dissolution $(\mathrm{pH} 4.5)$, formation of WSL around the orthodontic brackets was verified. Nevertheless, in the area around the fluoridated resin, a WSL inhibition zone could be noted, attributing the lower degree of demineralization to the fluoride released and reincorporated by enamel (14). In this context, the Transbond Plus Color Change resin showed a better caries preventive effect, in comparison with Orthodontic Fill Magic in order to present a larger WSL inhibition zone.

Despite the fact that fluoride acts in reduction of WSL during orthodontic treatment, other studies have shown that the fluoride release of composite resins is 5 to $20 \%$ lower than that of glass ionomer cements (16). Moreover, the amount of fluoride incorporated into resins is insufficient and the period of time of fluoride release is short (17). The literature shows that fluoridereleasing materials present a "burst-effect" pattern of fluoride-release, the largest amount of fluoride being released within the first few days of testing, followed by a rapid decline to much lower levels, due to low levels of fluoride incorporated (18). However, generally studies that quantify fluoride release are conducted in water (19), which accelerates the release of fluoride, and do not simulate the oral environment. The present study was conducted using artificial saliva, seeking an ionic balance and more similarity to the dynamics occurring in the oral cavity, particularly because it has been shown that fluoride release in artificial saliva is slower than it is in water (20). Nevertheless, it is suggested that not only fluoride, but also the calcium present in the artificial saliva was incorporated into the dental tissue during the cariogenic challenges.

This study presented a satisfactory and assessable model for the study of caries prevention, using $\mathrm{pH}$ cycling in high cariogenic challenges, with hydroxyapatite and fluoridated hydroxyapatite $\mathrm{pH}$ dissolution, simulating in vivo conditions. The acidity of demineralization solution influenced the formation of WSL around orthodontic brackets under high cariogenic conditions. Based on the methodology applied, it was shown that Transbond Plus Color Change resin promoted greater inhibition of WSL around the brackets when subjected to high cariogenic challenge than Orthodontic Fill Magic, thus being indicated for patients who are highly susceptible to develop dental caries.

\section{RESUMO}

O objetivo do presente estudo foi avaliar in vitro o efeito preventivo a cárie de resinas ortodônticas fluoretadas submetidas à ciclagem de $\mathrm{pH}$ utilizando dois tipos de saliva desmineralizadora. Bráquetes de incisivos centrais foram colados em 60 incisivos bovinos, utilizando a resina ortodôntica Transbond Plus Color Change 
$(n=30)$ ou Fill Magic $(n=30)$. Cada grupo foi dividido em 3 subgrupos $(n=10)$ : imersão em saliva artificial remineralizante por 14 dias e simulação de alto desafio cariogênico com ciclagem de $\mathrm{pH}$ em saliva ácida com $\mathrm{pH}$ 5,5 ou pH 4,5. Após 14 dias de ciclagem de $\mathrm{pH}$, o efeito preventivo de cárie foi avaliado por meio da formação de halo de inibição da mancha branca, adotando-se os escores: 0-ausência e 1-presença. Os testes Kruskal Wallis e Man-Whitney $(\alpha=0,05)$ foram aplicados. A formação de lesões de mancha branca foi observada somente na ciclagem de $\mathrm{pH}$ com saliva ácida a $\mathrm{pH} 4,5$; sendo o Transbond Plus Color Change significantemente mais efetivo na prevenção ao desenvolvimento de mancha branca quando comparados ao Fill Magic $(\mathrm{p}<0,05)$. $\mathrm{O} \mathrm{pH}$ da solução desmineralizante influenciou na formação de lesões de mancha branca circunjacentes aos bráquetes em condições de alto desafio cariogênico. A Transbond Plus Color Change apresentou maior efeito preventivo de cárie em relação ao Fill Magic.

\section{ACKNOWLEDGEMENTS}

The authors thank FAPERJ for the financial support.

\section{REFERENCES}

1. Tavares SW, Consani S, Nouer DF, Magnani MB, Nouer PR, Martins LM. Shear bond strength of new and recycled brackets to enamel. Braz Dent J 2006; 17:44-48.

2. Algera TJ, Kleverlaan CJ, Prahl-Andersen B, Feilzer AJ. The influence of different bracket base surfaces on tensile and shear bond strength. Eur J Orthod 2008;30:490-494.

3. Pithon MM, Oliveira MV, Ruellas AC, Bolognese AM, Romano FL. Shear bond strenght of orthodontic brackets to enamel under different surface treatment conditions. J Appl Oral Sci 2007; 15:127-130.

4. Passalini P, Fidalgo TKS, Caldeira EM, Gleiser R, Nojima MCG, Maia LC. Mechanical properties of one and two-step fluoridated orthodontic resins submitted to different $\mathrm{pH}$ cycling regimes. Braz Oral Res 2010;24:197-203.

5. Gorton J, Featherstone JD. In vivo inhibition of demineralization around orthodontic brackets. Am J Orthod Dentofacial Orthop 2003;123:10-14

6. Benson PE, Parkin N, Millett DT, Dyer FE, Vine S, Shah A. Fluorides for the prevention of white spots on teeth during fixed brace treatment. Cochrane Database Syst Rev 2004:CD003809.
7. Benson PE, Shah AA, Millett DT, Dyer F, Parkin N, Vine RS Fluorides, orthodontics and demineralization: a systematic review. J Orthod 2005;32:102-114.

8. Bishara SE, Soliman M, Laffoon JF, Warren J. Shear bond strength of a new high fluoride release glass ionomer adhesive. Angle Orthod 2008;78:125-128.

9. Queiroz CS, Hara AT, Paes Leme AF, Cury JA. pH-cycling models to evaluate the effect of low fluoride dentifrice on enamel de- and remineralization. Braz Dent J 2008;19:21-27.

10. Lammers PC, Borggreven JM, Driessens FC. Acid-susceptibility of lesions in bovine enamel after remineralization at different $\mathrm{pH}$ values and in the presence of different fluoride concentrations. J Dent Res 1991;70:1486-1490.

11. Damato FA, Strang R, Stephen KW. Effect of fluoride concentration on remineralization of carious enamel: an in vitro pH-cycling study. Caries Res 1990;24:174-180.

12. Ghani SH, Creanor SL, Luffingham JK, Foye RH. An ex vivo investigation into the release of fluoride from fluoride-containing orthodontic bonding composites. Br J Orthod 1994;21:239-243.

13. Sudjalim TR, Woods MG, Manton DJ, Reynolds EC. Prevention of demineralization around orthodontic brackets in vitro. Am J Orthod Dentofacial Orthop 2007;131:705 e701-709.

14. Qu H, Vasiliev AL, Aindow M, Wei M. Incorporation of fluorine ions into hydroxyapatite by a $\mathrm{pH}$ cycling method. J Mater Sci Mater Med 2005;16:447-453.

15. Wilson RM, Donly KJ. Demineralization around orthodontic brackets bonded with resin-modified glass ionomer cement and fluoride-releasing resin composite. Pediatr Dent 2001;23:255-259.

16. Dijkman GE, de Vries J, Lodding A, Arends J. Long-term fluoride release of visible light-activated composites in vitro: a correlation with in situ demineralisation data. Caries Res 1993;27:117-123.

17. Lin YC, Lai YL, Chen WT, Lee SY. Kinetics of fluoride release from and reuptake by orthodontic cements. Am J Orthod Dentofacial Orthop 2008;133:427-434.

18. Cohen WJ, Wiltshire WA, Dawes C, Lavelle CL. Long-term in vitro fluoride release and rerelease from orthodontic bonding materials containing fluoride. Am J Orthod Dentofacial Orthop 2003;124:571-576.

19. Adair SM, Whitford GM, McKnight-Hanes C. Effect of artificial saliva and calcium on fluoride output of controlled-release devices. Caries Res 1994;28:28-34.

20. Erickson RL, Glasspoole EA. Model investigations of caries inhibition by fluoride-releasing dental materials. Adv Dent Res 1995;9:315-323; discussion 324-331.

Accepted June 22, 2010 